\title{
Social Capital: an Efficient Instrument for Sustainable Development (Algeria 1990 -2012)
}

\author{
Pr.Diab Zeggai \\ Pr. Bensekrane Boudali
}

Faculty of Economics and Management, University of Saida.- Alegria

doi: 10.19044/esj.2016.v12n25p415 URL:http://dx.doi.org/10.19044/esj.2016.v12n25p415

\begin{abstract}
The studies on the development and well-being focused on the tools and the instruments and declaration of economic reforms which accelerated significantly to put civil society under study and look after stages of the experiment and application, where after the first generation of reforms during the period [1980-1988], what are known as financial restructuring and organic and structural adjustment programs, which support the orientation to a market economy; then the second generation of reforms [1990-1996] on the government's work in order to define the impact and effectiveness on economic activity. Finally, the last generation came on the role of civil society, that considering the networks, trust and participation become a major research under the title of "social capital".
\end{abstract}

Keywords: Social Capital - Networks - Participation - SustainableDevelopment

\section{Introduction}

The first time appeared in a "Community Center" in 1916 by Lyda Judson Hanifan - in the debate about educational centers and rural communities in the United States of America, a formulation of the concept that the involvement of relations friendly, natural and friendly, mutual solidarity cooperative that characterize of the society Members, and these relations themselves contain the wealth capital useful in order to raise the welfare; after that, it was used by Jacobs 1961 in "the life and Death of Great American Cities" in his analysis of urban districts, then publish the standard experimental study to compare with the human capital in the article published in "A Real Dynamic Theory Of Racial Income Differences" 1977 by Loury who considered that the social capital refers to the relationship of trust and authority, and social norms adhered in the social environment. Till the end of the 1970s, the Social Capital Theory remained an initial search because the 
concept was used in a little theoretical and experimental analysis, then we find that intrigued a sociologies and economists at the beginning of the year 1980 with the work P.Bourdieu and after the Americans(Coleman, 1988) and (Putnam, 1995), while he studied the subject in detail in terms of the theoretical concept hand practical role and level search results, then following the publication of studies which varied to different disciplines (sociology, economics, management, education, public health, development, planning, environment, etc.) during the period between 1989 and 2005 in these countries: the United States 51\%, England 16\%, 8\%, Canada, Australia, 4\%, Germany $4 \%$, and in France with $3 \%$ In statistics in various specialized scientific, around the study of well-being social and his relationship with indicators of economic growth and the fight against poverty and unemployment and the good governance index.

\section{Theory Section:}

\subsection{The Concept of Social Capital of the Theorists}

The social capital "referring to the social construction features; networks, norms and trustworthiness that facilitate coordination and cooperation of mutual interests"(Putnam, 1995), and on the other side, it is the " the actual or potential resources which are linked to possession of a durable network of more or less institutionalized relationships or belonging to a group "(Bourdieu, 1980), and thus is a multi-criteria indicators for the concept of both theory and experimental (Grootaert \& Van Bastelaer, 2001) (Woolcock \& Narayan, 2000), or defined functionally as "a variety of entities with two elements in common: they all consist of some aspect of social structure, and they facilitate certain actions of actors... within the structure" (Coleman, 1988), it lies in communication between the working people and groups, is not limited, and riding in a person particularity just like the concept of human capital economic, where it lies in communication between the working people and groups, and is not limited to resign in person particularity just like the concept of human and economic capital, and therefore the social capital characteristics of sources, determinants, components, types and forms and also all of its uses and its impact take a variety of formats, as well as multiple social fields, economic, political and at different levels, micro, macro and between them. Accordingly, the theme that combines both these fields and levels must be to acquire the outstanding reflected the importance of the concept of "social capital", however, we find international institutions like the World Bank and the Organization for Economic Cooperation and Development OCDE which had an important role in controlling the development of the subject and work around it by publishing articles and enabling the informant laboratory specialized, when the OECD defines Social Capital as "networks together with 
shared norms, values and understandings that facilitate cooperation within or among groups". You see it every time it is defined either by the result obtained resources as when P.Bourdieu and others, or through functionally definition of facilitate operations as when R.Putnam and J.Coleman and others.

\subsection{Social Capital and its Properties:}

First, its sources, a total social organizations and communities within the social construction of partial total, which takes the same characteristics and features of this construction (civil society), has been identified as the family - school - organizations - civil society - the public sector -Social groups communities - ethnicity - the complementary male / female. Second, we have the components and determinants which take three levels: i. Construction index (structural) ii. Relations and communications index (relational) iii.

Cognitive Index, a much investigator of shared norms, values, as well as having the confidence and stimulate exchange and access to information, public goods, and forms of social capital, types, and from our internal networks between the same symmetric group "united" BONDING members, external networks between members of different groups asymmetric Association "BRIDGING". Third, networks with macro-level authority "LINKING", and in the same context, if we look at the impact of these networks (Burt, 2009; Fafchamps, 2002; Lin, 2002; Ostrom, 2014), see that the social capital takes three types: i. Unified social capital. ii. The link between the various groups and membership iii. Inclusive of integrating organic and gatherings of exotic(Bourdieu, 1980; Putnam, 1995; Ritzen \& Woolcock, 2000), in parallel; we find the public and private [Profile - family case is attributed matter focused on the actor and the intervener in its composition and its uses.

Figure 1: Forms and the determinants and scope of social capital

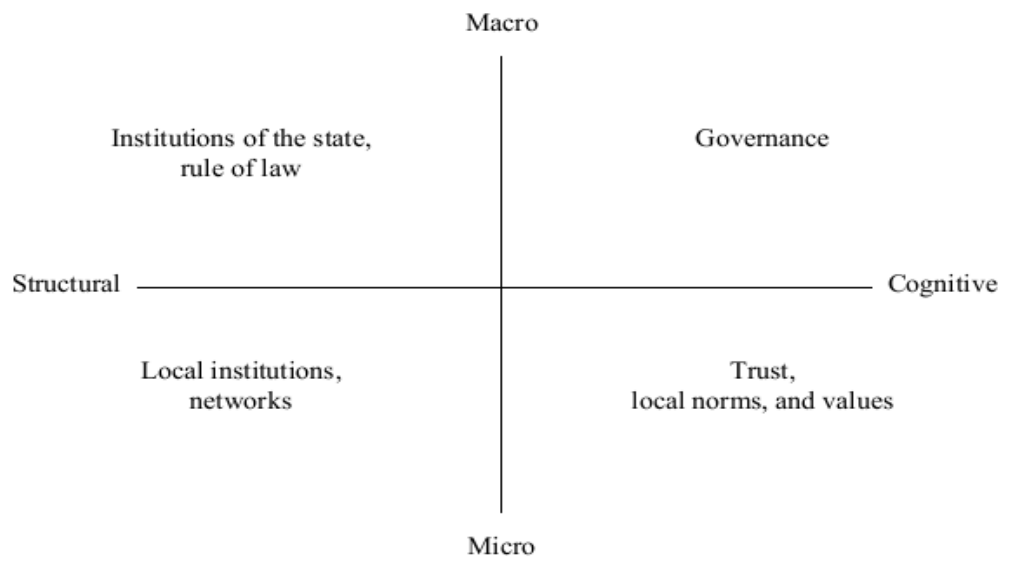

Source: (Grootaert \& Van Bastelaer, 2001) 


\subsection{Uses Social Capital for Economic Development and the Well-being:}

This rich concept of social capital gives fertile ground for Search Appear in the impact and versatility in social areas (education and health), economic and political .., R.Putnam, as demonstrated in his work on the United States in the "bowling alone" 2000, while the detection of the relationship and the degree of correlation experimentally between social capital and indicators study, such as the efficiency of the education within the various states index, tax evasion rate, health index, the rate of violence and crime and the rate of economic and social equalizer and others, as well as in the previous study on Italy in a "Making Democracy Work" 1993 at the comparison between north and south Italy, which focused on the effectiveness of government administration. As a result, influenced by social capital in the evolution, including the existence of networks and civic participation, trust and integration, and the study on Italy came after a period of reforms applicable to government institutions [1976-1977].

Figure 2: The Social Capital and the Dimensions of Sustainable Development

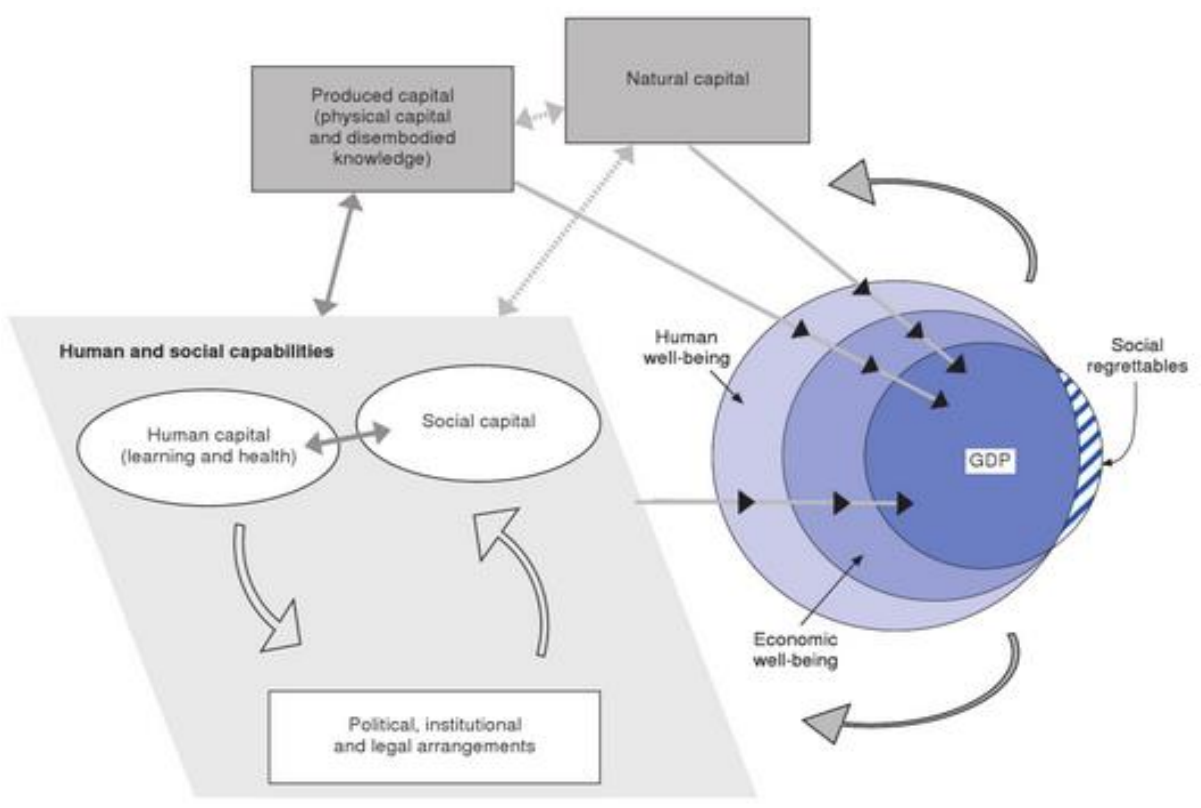

Source: (recherche \& l'enseignement, 2001)

In the Beginning, the terms of social capital and sustainable development must adjust the concept and identify goals that are consistent in large part with the goals of social capital, so that the tools available in this aspect of our Collective Action and Cooperation - to expand trust and exchange - common rules and facilitate the operations and research - in the effort to reduce the cost and time - information and communication - the role 
of networks: Bonding; Bridging; Linking - provision of public goods and basic services (education / health / security ..) - also the role of social capital in the creation of human capital (Coleman, 1988), and (Fafchamps, 2002) studies on important dimensions of social capital; a trust and efficiency of social exchange, search and social networking, equity and participation, and focus on the role of social capital in economic development will be primarily on the study of its relationship with the rest of varieties of capital relating to capitalfinancial, economic and human (Bourdieu, 1980; Coleman, 1988; Lévesque \& White, 1999; Lin, 2002), and its role in the converted(recherche \& l'enseignement, 2001) because it is associated to these types of capital available among them, Where it becomes the center and the channel of the convergence to facilitates operations between agents economists within organizations and various groups, here we have the reference to the role of government work in parallel with the role of civil society (figure 3) in the complementarily relationship refers to the optimal interaction of government and markets in civil society, and substitution relationship is the replacement by informal organization (families, networks and soon) of services ordinarily provided by governments and institutions (Woolcock \& Narayan, 2000) according to the four levels when there is social capital intensity with the Good governance (Kaufmann \& Kraay, 2008); So the sustainable development is to be achieved.

Figure 3 : Relationship between social capital and governance

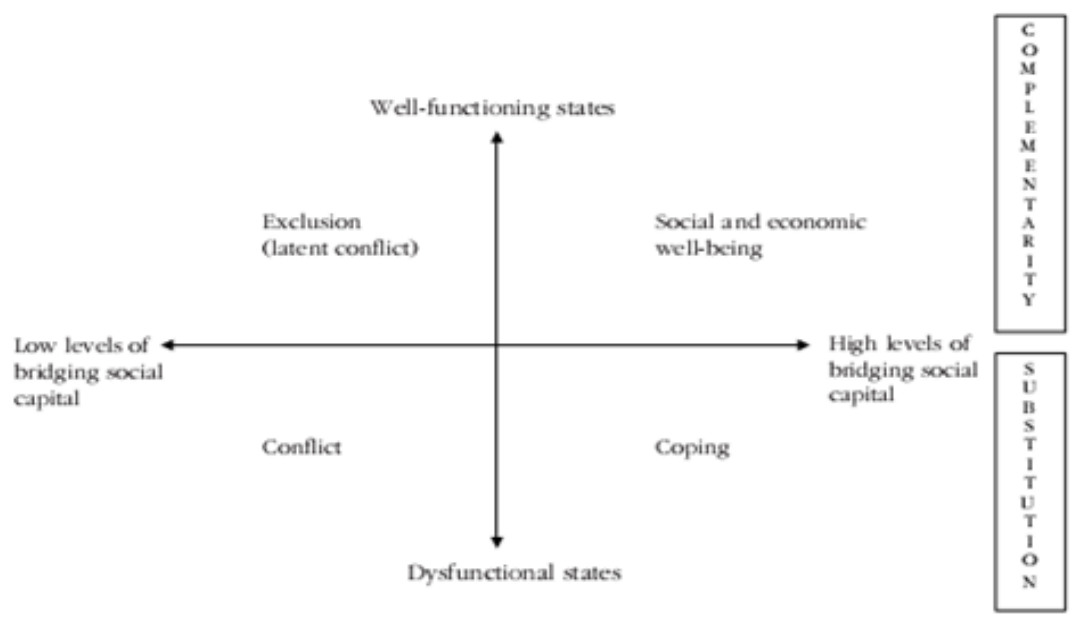

Source: (Woolcock \& Narayan, 2000)

In parallel to that "social capital; it's not what you know; it's who you know", we find to benefit from the uses of social capital tools in the fight against poverty and unemployment (Figure 4), remain the other of the 
objectives of economic development, as the interdependence and integration and against marginalization, conflict and loss of confidence and collective action, and vice exclusion and marginalization, poor networking and isolation increases the poverty, unemployment and social conflict and criminality and loss of confidence and loss of cooperative teamwork and the weakness of the information and the lack of contact the main factor to support the exchange and integration and to provide opportunities and take advantage of them.

Figure 4: the social indicators and the transition level of income by investing networks

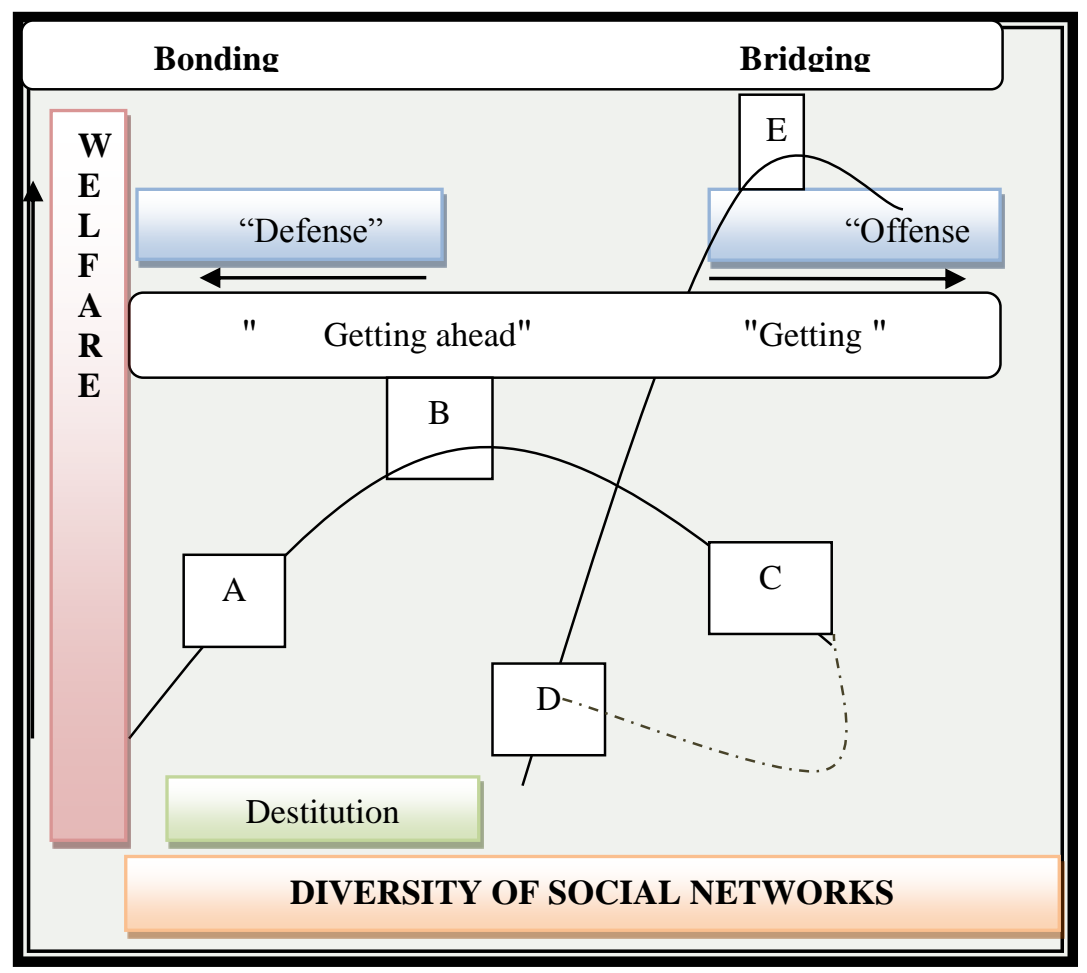

Source: (Woolcock \& Narayan, 2000)

\subsection{Theory Conclusion:}

The previous definitions of social capital focus on the social structure, groups and networks, and the social features like the norms, trustworthiness, Solidarity and the information; therefore, we can study the uses of social capital in sustainable development through the following basic ideas:

- The economic development and human well-being

- Social capital and its relationship to the rest of the types of capital (financial and material).

- The creation of the intellectual and human capital.

- The fight against poverty and unemployment.

- Strengthen governance and fight corruption 


\section{Practical Section}

\subsection{Social Capital Indicators and Measuring the Level and Density:}

"You Can Not Compare When Can Not Measure", Permission must determine the composition and level of social capital, international and comparative measurement standards, which work by a group of researchers (Grootaert \& Van Bastelaer, 2001; Woolcock \& Narayan, 2000) competent at the World Bank (SOCAT) in their studies and research multiple, where the selection indicators came from the concepts of social capital by reference to empirical studies published around and most used variables, whether at personal micro level or the macro level, with which to study the evolution and its relationship with economic development and human well-being indicators, and government index, and enable to make international comparisons, and development of studies about that, these 6 six indicators are measured by a special form a questionnaire based on the data available, depending on the status of civil society from region to another as follows :

2.1.1 Groups and Networks $\leftarrow$ Formative Index

2.1.2 Trust and Solidarity $\leftarrow$ Formative Index

2.1.3 Collective Action and Cooperation $\leftarrow$ Index practical and functional

2.1.4 Information and Communication $\leftarrow$ Index practical and functional

2.1.5 Social Cohesion and Inclusion $\leftarrow$ result, effectiveness index

2.1.6 Empowerment and Political Action $\leftarrow$ result, effectiveness index

\subsection{Algeria's Case Study 1990-2012:}

\subsubsection{Material and Methods}

In order to study the effect of social capital and its role in sustainable development, we selected four groups of the dimensions of development:

- human and intellectual capital indicators

- the economic and financial indicators

- social capital indicators

- good governance indicators

To Applied study, there are three stages that use the statistical program EVIEWS 8:

- First, study the correlation between social indicators and financial indicators and indicators of government action.

- Second, Augmented Dickey-Fuller test (ADF) to uncover the unity root.

- Third, we examine Granger causality test. 


\subsubsection{Measuring the impact of social capital indicators:}

\subsubsection{Correlation table between social indicators and financial indicators and indicators of government action}

\begin{tabular}{|c|c|c|c|c|c|c|c|c|c|c|c|}
\hline \multirow[b]{2}{*}{ global axis } & \multicolumn{4}{|c|}{ human capital indicators and intellectual } & \multicolumn{5}{|c|}{ The economic and financial indicators } & \multicolumn{2}{|c|}{ Social Dimensions } \\
\hline & $\begin{array}{c}\text { fight } \\
\text { corruption }\end{array}$ & $\begin{array}{c}\text { Patent } \\
\text { applications }\end{array}$ & $\begin{array}{l}\text { trademark } \\
\text { registration }\end{array}$ & Labor force & Exchange rate & gn direct inves & inflation & ompetitivenes & dp_per_capit & And government & actior \\
\hline $0.90 * *$ & 0.409 & $0.707 * *$ & 0.104 & $0.958^{* *}$ & $0.957 * *$ & $0.758^{* *}$ & 0.307 & $0.692 * *$ & $* 0.613$ & Organic rate & \\
\hline $0.902 * *$ & 0.412 & $0.719 * *$ & 0.092 & $0.956 * *$ & $0.946^{* *}$ & $0.746^{* *}$ & 0.358 & $0.847 * *$ & $* 0.549$ & \begin{tabular}{|c|} 
The evolution of \\
organizations
\end{tabular} & \\
\hline $0.969 * *$ & $0.493 *$ & $0.773 * *$ & 0.165 & $0.994 * *$ & $0.977 * *$ & $0.745^{* *}$ & 0.130 & $0.463^{*}$ & $* 0.514$ & $\begin{array}{l}\text { Trust and } \\
\text { solidarity } \\
\end{array}$ & $\underbrace{0}_{0}$ \\
\hline $0.963^{* *}$ & 0.477 & $0.769 * *$ & 0.157 & $0.994 * *$ & $0.979 * *$ & $0.753^{* *}$ & 0.135 & $0.473^{*}$ & $* 0.530$ & $\begin{array}{l}\text { Collective Action } \\
\text { and Cooperation }\end{array}$ & $\frac{\Xi}{\Xi}$ \\
\hline $0.970 * *$ & $0.593 *$ & $0.898 * *$ & 0.262 & $0.917 * *$ & $0.883 * *$ & $0.677^{* *}$ & 0.197 & $0.548 *$ & 0.363 & \begin{tabular}{|c|} 
Information and \\
Communication \\
\end{tabular} & \\
\hline $0.747 * *$ & $0.491^{*}$ & $0.637 *$ & 0.243 & $0.771 * *$ & $0.760 * *$ & 0.359 & $0.550 *$ & $0.628 *$ & $* 0.259$ & \begin{tabular}{|c|} 
Social Cohesion \\
and Inclusion \\
\end{tabular} & \\
\hline $0.906 * *$ & $0.929 * *$ & 0.129 & 0.770 ** & 0.5 & $0.753 * *$ & $0.937 * *$ & $0.637 * *$ & 0.228 & $0.583^{* *}$ & global axis & \\
\hline 0.419 & $0.492 *$ & 0.390 & 0.176 & $0.526 *$ & 0.666 ** & 0.453 & $0.594 * *$ & $0.605^{* *}$ & 0.315 & $\begin{array}{c}\text { Transparency and } \\
\text { accountability }\end{array}$ & \\
\hline$* * 0.650$ & $* 0.561$ & $* * 0.830$ & 0.447 & $* * 0.810$ & $* * 0.860$ & $* * 0.598$ & $* * 0.683$ & $* * 0.687$ & $0.155-$ & Political stability & $\begin{array}{cc}\tilde{U} & 0 \\
0 & 0\end{array}$ \\
\hline 0.464 & $* * 0.856$ & $* 0.593$ & 0.377 & $* 0.576$ & $* * 0.683$ & 0.266 & $* 0.519$ & 0.416 & 0.062 & $\begin{array}{c}\text { effective } \\
\text { government }\end{array}$ & 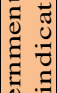 \\
\hline $0.130-$ & 0.146 & 0.065 & $0.085-$ & 0.053 & 0.245 & $* 0.473$ & 0.216 & 0.232 & $* 0.491$ & regulatory quality & \\
\hline *0.537 & 0.360 & $* 0.540$ & 0.281 & $\div * 0.709$ & $* * 0.825$ & $=* * 0.611$ & $* * 0.721$ & $\div * 0.757$ & 0.159 & regle de droit & \\
\hline
\end{tabular}

Source: From our preparation of statistical program EVIEWS 8 output 
2.2.2.2 Augmented Dickey-Fuller test (ADF)

\begin{tabular}{|c|c|c|c|c|c|c|c|}
\hline \multirow{3}{*}{\multicolumn{2}{|c|}{ Indicators }} & \multicolumn{6}{|c|}{ ADF test at the signal of $0.05=\alpha$} \\
\hline & & \multicolumn{3}{|c|}{ LEVEL } & \multicolumn{3}{|c|}{ When the first $*$ or second differences $* *$} \\
\hline & & $\mathrm{t}$ calcul & $\mathrm{t}$ refere & decision & $t$ calcul & $t$ refere & decision \\
\hline \multirow{6}{*}{$\begin{array}{c}\text { Social } \\
\text { Indicators }\end{array}$} & Organic rate & $3.690-$ & $2.555-$ & No & $1.962-$ & $3.876-$ & ** stationarity \\
\hline & $\begin{array}{l}\text { The } \\
\text { evolution of } \\
\text { organizations }\end{array}$ & $3.710-$ & $2.230-$ & No & $3.065-$ & $4.026-$ & ** stationarity \\
\hline & \begin{tabular}{|c|}
$\begin{array}{c}\text { Trust and } \\
\text { solidarity }\end{array}$ \\
\end{tabular} & $3.673-$ & $1.799-$ & No & $3.029-$ & $6.636-$ & * stationarity \\
\hline & $\begin{array}{l}\text { Collective } \\
\text { Action and } \\
\text { Cooperation } \\
\end{array}$ & $3.673-$ & $0.711-$ & No & $3.029-$ & 8.960- & * stationarity \\
\hline & \begin{tabular}{|c|}
$\begin{array}{c}\text { Information } \\
\text { and } \\
\text { Communicati } \\
\text { on }\end{array}$ \\
\end{tabular} & $3.658-$ & 0.209 & No & $3.052-$ & $6.928-$ & ** stationarity \\
\hline & \begin{tabular}{|c|} 
Social \\
Cohesion \\
and Inclusion \\
\end{tabular} & $3.791-$ & $5.569-$ & stationarity & & & \\
\hline \multicolumn{2}{|c|}{ global axis } & $3.65-$ & $7.66-$ & stationarity & & & \\
\hline \multirow{6}{*}{$\begin{array}{c}\text { The financial } \\
\text { indicators }\end{array}$} & $\begin{array}{c}\text { Net } \\
\text { domestic } \\
\text { credit }\end{array}$ & $3.62-$ & $1.43-$ & No & $3.00-$ & 3.39- & *stationarity \\
\hline & $\begin{array}{c}\text { Outstanding } \\
\text { claims }\end{array}$ & $3.62-$ & $5.44-$ & stationarity & & & \\
\hline & Total savings & $3.62-$ & $1.86-$ & No & $3.63-$ & $5.84-$ & * stationarity \\
\hline & \begin{tabular}{|l|} 
GDP \\
\end{tabular} & $3.62-$ & $49.08-$ & stationarity & & & \\
\hline & $\begin{array}{c}\text { Total fixed } \\
\text { capital } \\
\text { formation }\end{array}$ & $4.10-$ & $0.10-$ & stationarity & $3.32-$ & 8.00- & ** stationarity \\
\hline & $\begin{array}{c}\text { The added } \\
\text { value }\end{array}$ & $3.61-$ & $2.18-$ & No & $3.00-$ & $5.81-$ & * stationarity \\
\hline \multicolumn{2}{|c|}{ global axis } & $3.62-$ & $3.69-$ & stationarity & & & \\
\hline \multirow{5}{*}{$\begin{array}{l}\text { The } \\
\text { economic } \\
\text { indicators }\end{array}$} & $\underset{\text { pita }}{\text { gdp_per_ca }}$ & $3.622-$ & $3.076-$ & No & $3.004-$ & $6.031-$ & * stationarity \\
\hline & $\begin{array}{c}\text { competitivene } \\
\text { ss } \\
\end{array}$ & $3.622-$ & $1.991-$ & No & $3.012-$ & 7.953- & $* *$ stationarity \\
\hline & inflation & $3.632-$ & $4.351-$ & stationarity & & & \\
\hline & $\begin{array}{c}\text { Foreign } \\
\text { direct } \\
\text { investment }\end{array}$ & $3.622-$ & $3.655-$ & stationarity & & & \\
\hline & $\begin{array}{c}\text { Exchange } \\
\text { rate }\end{array}$ & $3.622-$ & $1.114-$ & No & $3.004-$ & $3.504-$ & * stationarity \\
\hline \multicolumn{2}{|c|}{ global axis } & $3.62-$ & $1.34-$ & No & No & $3.87-$ & $*$ stationarity \\
\hline \multirow{4}{*}{$\begin{array}{c}\text { human } \\
\text { capital } \\
\text { indicators } \\
\text { and } \\
\text { intellectual }\end{array}$} & Labor force & $3.63-$ & $2.71-$ & No & $3.01-$ & $5.33-$ & $* *$ stationarity \\
\hline & $\begin{array}{c}\text { Patent } \\
\text { applications }\end{array}$ & $3.67-$ & 0.016 & No & $3.08-$ & $4.71-$ & ** stationarity \\
\hline & $\begin{array}{c}\text { trademark } \\
\text { registration }\end{array}$ & $3.63-$ & $4.53-$ & stationarity & & & \\
\hline & $\begin{array}{c}\text { fight } \\
\text { corruption }\end{array}$ & $3.71-$ & No & No & $3.06-$ & $3.96-$ & * stationarity \\
\hline
\end{tabular}

Source: From our preparation of statistical program EVIEWS 8 output 


\subsubsection{Granger causality test:}

\begin{tabular}{|c|c|c|c|c|c|c|c|c|c|c|c|c|c|c|c|c|c|c|c|}
\hline \multirow{3}{*}{\multicolumn{2}{|c|}{$\begin{array}{l}\text { Dimensions of } \\
\text { development }\end{array}$}} & \multicolumn{18}{|c|}{ dimensions of social capital } \\
\hline & & \multicolumn{3}{|c|}{ Organic rate } & \multicolumn{3}{|c|}{$\begin{array}{c}\text { The evolution of } \\
\text { organizations }\end{array}$} & \multicolumn{3}{|c|}{ trust } & \multicolumn{3}{|c|}{$\begin{array}{c}\text { Collective Action and } \\
\text { Cooperation }\end{array}$} & \multicolumn{3}{|c|}{$\begin{array}{r}\text { Information and } \\
\text { Communication }\end{array}$} & \multicolumn{3}{|c|}{$\begin{array}{c}\text { Social Cohesion and } \\
\text { Inclusion }\end{array}$} \\
\hline & & F CAL & \begin{tabular}{|c|}
$\alpha$ \\
PROP \\
\end{tabular} & $\begin{array}{r}\text { Typeof } \\
\text { relation } \\
\end{array}$ & F CAL & \begin{tabular}{|c|}
$\alpha$ \\
PROP \\
\end{tabular} & $\begin{array}{r}\text { Typeof } \\
\text { relation } \\
\end{array}$ & F CAL & $\begin{array}{c}\text { A } \\
\text { PROP } \\
\end{array}$ & \begin{tabular}{|r|}
$\begin{array}{r}\text { Typeof } \\
\text { relation }\end{array}$ \\
\end{tabular} & F CAL & \begin{tabular}{|c|}
$\alpha$ \\
PROP \\
\end{tabular} & $\begin{array}{r}\text { Typeof } \\
\text { relation } \\
\end{array}$ & F CAL & F TAB & 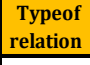 & F CAL & \multicolumn{2}{|c|}{\begin{tabular}{|c||c}
$\alpha$ & Typeof \\
PROP & relation \\
\end{tabular}} \\
\hline \multirow{5}{*}{ 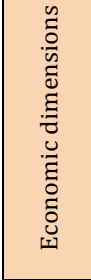 } & gdp_per_capita & 1.25 & 0.31 & mutual & 0.35 & 0.70 & mutual & $\mid 2.89$ & 0.06 & unilate & 2.44 & 0.12 & mutual & 0.19 & 0.82 & unilate & 0.91 & 0.43 & mutual \\
\hline & competitiveness & 2.45 & 0.12 & mutual & 2.57 & 0.11 & unilate & 2.44 & 0.12 & mutual & 2.59 & 0.11 & unilate & 1.08 & 0.36 & mutual & 0.72 & 0.51 & mutual \\
\hline & inflation & 3.34 & 0.03 & no & 3.40 & 0.04 & no & 2.23 & 0.14 & mutual & 2.96 & 0.08 & mutual & 1.39 & 0.02 & no & 0.66 & 0.03 & no \\
\hline & $\begin{array}{l}\text { For eign direct } \\
\text { investment }\end{array}$ & 3.09 & 0.04 & no & 3.00 & 0.08 & mutual & 3.28 & 0.03 & no & 3.79 & 0.04 & no & 1.32 & 0.29 & unilate & 2.52 & 0.14 & mutual \\
\hline & Exchange rate & 0.66 & 0.53 & mutual & 1.17 & 0.34 & unilate & 2.63 & 0.02 & no & 2.67 & 0.10 & unilate & 0.03 & 0.96 & mutual & 0.01 & 0.98 & unilate \\
\hline \multicolumn{2}{|r|}{ global axis } & 0.16 & 0.85 & mutual & 0,29 & 0.75 & mutual & $\mid 0.87$ & 0.44 & mutual & 0.74 & 0.49 & mutual & 0.07 & 0.92 & mutual & $\mid$\begin{tabular}{||c|c|}
0.38 \\
\end{tabular} & 0.69 & unilate \\
\hline \multirow{4}{*}{ 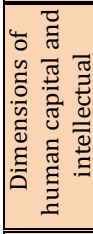 } & Labor force & 0.31 & 0.73 & mutual & 0.36 & 0.70 & mutual & 2.56 & 0.11 & mutual & 3.62 & 0.06 & mutual & 0.05 & 0.94 & mutual & 2.09 & 0.18 & unilate \\
\hline & Patent applications & 0.14 & 0.87 & mutual & 0.03 & 0.96 & mutual & 1.17 & 0.33 & mutual & 3.69 & 0.04 & no & 5.81 & 0.01 & no & 10.9 & 0.00 & no \\
\hline & $\begin{array}{r}\text { trademark } \\
\text { registration }\end{array}$ & 2.08 & 0.17 & mutual & 5.25 & 0.03 & no & 0.55 & 0.58 & mutual & 0.16 & 0.84 & mutual & 0.27 & 0.76 & mutual & 2.31 & 0.17 & mutual \\
\hline & fight corruption & 0.81 & 0.47 & mutual & 0.38 & 0.69 & mutual & 0.49 & 0.62 & $\begin{array}{c}\text { unilater } \\
\text { al }\end{array}$ & 0.11 & 0.88 & mutual & 0.24 & 0.78 & mutual & $\mid$\begin{tabular}{||l}
2.79 \\
\end{tabular} & 0.12 & mutual \\
\hline \multicolumn{2}{|r|}{ global axis } & 0.17 & 0.84 & mutual & 0,08 & 0.92 & mutual & 0,21 & 0.81 & mutual & 0.04 & 0.95 & unilate & 5.45 & 0.02 & no & 0.54 & 0.59 & mutual \\
\hline & Net domestic credit & 0.95 & 0.41 & mutual & 0.58 & 0.57 & mutual & 0.77 & 0,48 & mutual & 0.29 & 0.74 & mutual & 3.34 & 0.07 & mutual & 4.37 & 0.04 & no \\
\hline 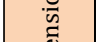 & Outstanding claims & 1.02 & 0.39 & mutual & 4.07 & 0.03 & no & 18.60 & 0.00 & no & 17.5 & 0.00 & no & 0.28 & 0.75 & mutual & 3.84 & 0.06 & unilate \\
\hline$\Xi$ & Total savings & 1.90 & 0.19 & mutual & 1.31 & 0.31 & mutual & 1.46 & 0.26 & mutual & 0.94 & 0.41 & mutual & 3.46 & 0.06 & mutual & 0.55 & 0.59 & mutual \\
\hline & GDP & 2.78 & 0.10 & mutual & 1.09 & 0.37 & mutual & 6.34 & 0.01 & mutual & 4.68 & 0.02 & no & 0.08 & 0.91 & mutual & 1.07 & 0.38 & unilate \\
\hline$\stackrel{0}{\Xi}$ & $\begin{array}{l}\text { fixed capital } \\
\text { formation }\end{array}$ & 0.19 & 0.83 & mutual & 3.17 & 0.36 & mutual & 5.35 & 0.10 & mutual & 7.05 & 0.07 & unilate & 3.29 & 0.17 & mutual & 2.54 & 0.03 & no \\
\hline & The added value & 1.66 & 0,23 & mutual & 0.87 & 0,44 & mutual & 0.75 & 0.48 & mutual & 0.48 & 0,62 & mutual & 2.37 & 0.13 & mutual & 0.19 & 0,82 & mutual \\
\hline & global axis & 0.18 & 0.83 & mutual & 0.03 & 0.96 & mutual & 2.60 & 0.10 & mutual & 0.70 & 0.51 & mutual & 21.2 & 0.00 & no & 0.96 & 0.42 & mutual \\
\hline
\end{tabular}

Source: From our preparation of statistical program EVIEWS 8 output

\subsubsection{Result and Discussion}

- There is a strong signal correlation between social capital and good governance indicators with economic development indicators.

- The Stability achieved in the level or the first and second delay for all development indicators.

- Granger causality test was mutual (reciprocity) or unilateral between social capital indicators and economic development indicators, but is not for a few cases because the data type of the country. 


\section{Conclusion}

The development of strategies and government policies and programs that focus on social capital has a positive impact which is to overcome the obstacles to development communities and business organizations of various countries, especially in the third world countries and to support the urgent need to provide resources social and basic services for the sustainable well-being by following:

- The accumulation of social capital indicators and the provision of public goods

- Integrating types of capital [financial, economic, human (intellectual)].

- Exchange of experience and skill transfer and raise the level of accumulation of intellectual and human capital.

- Collective Action and social cohesion (specialization and integration)

- The Innovations and the creation of value added (wealth), competitiveness and continuity.

- Effectiveness, efficiency and transparency to enhance the governance and control of corruption.

\section{References:}

Adler, P. S., \& Kwon, S.-W. (2002). Social capital: Prospects for a new concept. Academy of management review, 27(1), 17-40.

Bourdieu, P. (1980). Le capital social. Actes de la recherche en sciences sociales, 31(1), 2-3.

Burt, R. S. (2009). Structural holes: The social structure of competition: Harvard university press.

Coleman, J. S. (1988). Social capital in the creation of human capital. American journal of sociology, S95-S120.

Fafchamps, M. (2002). Social capital, trust, and development. Social development strategy. Washington DC: The World Bank.

Granovetter, M. S. (1973). The strength of weak ties. American journal of sociology, 1360-1380.

Grootaert, C., \& Van Bastelaer, T. (2001). Understanding and measuring social capital: A synthesis of findings and recommendations from the social capital initiative (Vol. 24): World Bank, Social Development Family, Environmentally and Socially Sustainable Development Network.

Group, W. B. (2012). World Development Indicators 2012: World Bank Publications.

Hanifan, L. J. (1916). The rural school community center. The Annals of the American Academy of Political and Social Science, 67, 130-138. 
Kaufmann, D., \& Kraay, A. (2008). Governance indicators: Where are we, where should we be going? The World Bank Research Observer, 23(1), $1-30$.

Kaufmann, D., Kraay, A., \& Zoido-Lobatón, P. (1999). Aggregating governance indicators (Vol. 2195): World Bank Publications.

Knack, S., \& Keefer, P. (1997). Does social capital have an economic payoff? A cross-country investigation. The Quarterly journal of economics, 1251-1288.

Lévesque, M., \& White, D. (1999). Le concept de capital social et ses usages. Lien social et politiques(41), 23-33.

Lin, N. (2002). Social capital: A theory of social structure and action (Vol. 19): Cambridge university press.

Lopez-de-Silanes, R., La Porta, R., Shleifer, A., \& Vishny, R. (1997). Trust in Large Organizations. The American Economic Review, 87(2), 333338.

Ndayegamiye, A. (2007). Élargir le champ de conception des indicateurs sociaux: Proposition d'une approche relationnelle à partir du contexte socioéconomique des années 90. Cas du Burundi (Vol. 525): Presses univ. de Louvain.

Ostrom, E. (2014). Collective action and the evolution of social norms. Journal of Natural Resources Policy Research, 6(4), 235-252.

Pennar, K., \& Mueller, T. (1997). The ties that lead to prosperity. Business Week, 15(1), 153-154.

Putnam, R. D. (1995). Bowling alone: America's declining social capital. Journal of democracy, 6(1), 65-78.

Putnam, R. D., Leonardi, R., \& Nanetti, R. Y. (1994). Making democracy work: Civic traditions in modern Italy: Princeton university press.

recherche, C. p. 1., \& l'enseignement, i. d. (2001). Du bien-être des nations: le rôle du capital humain et social: OECD Publishing.

Ritzen, J., \& Woolcock, M. (2000). Social cohesion, public policy, and economic growth: implication for countries in transition. Paper presented at the Annual Bank Conference on Development Economics.

Sen, A. (1999). La possibilité du choix social [Conférence Nobel]. Revue de l'OFCE, 70(1), 7-61.

Weber, M. (1978). Economy and Society, ed. Guenther Roth and Claus Wittich (Berkeley: University of California Press, 1978), 1, 622-623.

Woolcock, M., \& Narayan, D. (2000). Social capital: Implications for development theory, research, and policy. The World Bank Research Observer, 15(2), 225-249. 